\title{
City Boosterism and Place-making with Light Rail Transit: a critical review of light rail impacts on city image and quality
}

As an agent in the production of place, transport plays a key role in shaping cities and their wider urban regions. Light rail transit can contribute to city boosterism - helping to enhance a city's image and quality towards broader development agendas such as economic growth and creation of sustainable and liveable cities. This paper examines the place-making role of light rail (supertrams, light metros and streetcars) through analysis of its material and meaningful impacts in relation to boosting city image and quality. It provides a critical synthesis of empirical ex-post evidence from a literature review of published and unpublished sources on wider economic impacts of light rail. Impacts include a modern image, reinforcement of cultural identity, prestige, social inclusion/exclusion, environmental quality, and physical transformations such as pedestrianisation and 'greening' the city. More positive impacts than negative impacts were found, though these vary with geographical location and over time. Some cities deliberately seek to maximise impacts through integrated transport and urban planning strategies. The paper complements existing cultural approaches to transport geography to shed light on the relationship between transit development and city boosterism. The paper makes recommendations for future research.

\section{Keywords}

Light rail transit; place-making; city boosterism; liveable cities; wider economic impacts; urban transport

\subsection{Introduction}

Light rail transit (LRT) (by which we refer to supertrams, light metros and streetcars) has been recognised, among academics and various stakeholders, as a tool to bring about social, economic and environmental benefits for medium- and large-sized cities, and urban regions, across the globe (Banister and Thurstain-Goodwin 2001). In developed countries, in particular, light rail has been promoted as a catalyst for broad development agendas such as urban regeneration and revitalisation (Babalik-Sutcliffe 2002; King and Fischer 2016; Knowles and Ferbrache 2015), as well as a focus for cities wishing to boost their status and prestige as 'world class', liveable or sustainable cities (Ferbrache and Knowles 2016; Paget-Seekins 2015; Vuchic 1999). Through a cultural geographic lens and conceptualisation of space as socially constructed, light rail can be understood as part of place-making strategies that help to rejuvenate individual streets, (re)produce urban spaces and, in turn, shape discourses about the city and its image. This paper brings together perspectives from transport and cultural geography to examine urban placemaking in the context of light rail impact and development. 


\subsubsection{Research Aims}

The aims of this paper are three-fold: (i) to explore a cultural geographic perspective as a way of conceptualising the relationship between light rail development and city boosterism; (ii) to evaluate existing empirical evidence in terms of what it reveals about (mainly) ex-post impacts of light rail on city image and quality; and (iii) to identity gaps in light rail literature and provide directions for future research.

The relationship between transit development and city boosterism has rarely been the primary focus of research on light rail, yet existing literature reveals many examples, which, when synthesised, provide deeper insight to this relationship. This paper is based on a critical review of empirical evidence from a wide range of LRT sources. The nature of the evidence calls for a qualitative methodology to capture meanings and significance of ideas and perceptions ascribed to light rail by social actors, as well as material elements of light rail that transform cities. Space, understood to be socially constructed through an assemblage of heterogeneous entities and their interrelations (Massey 2005), provides the theoretical terrain to conceptualise the relationship between light rail and city boosterism as one of place-making (Jensen 2013; Lefebvre 1991; Shields 1991).

The need for such research is paramount when recognising what Hensher (2016:289) refers to as a resurgence of "emotional ideology" in decision-making, including "a strong sense of imagery conditioning modal preferences for LRT" (see also Edwards and Makett 1996; Hensher and Mulley 2015). This emphasis on image also emerges in discourses on sustainable and liveable cities (Mulliner and Maliene 2011; Vuchic 1999). Yet, subjective assessments, as well as qualitative analysis of light rail, have been overlooked in the typical quantitative calculations that have provided justifications for acceptance or rejection of transit schemes. Cost benefit analyses (CBA), for example, have been unable to place numeric value on social, environmental and wider economic effects, or incorporate subjective ideas and perceptions (Pickrell 1992; van Wee and Rietveld 2013). The extent and influence of "emotional ideology" in transit decision-making is not always clear, and while ex-ante decisions are not the focus of this paper, ex-post impacts become empirically specifiable as "social discourses on space which (1) underpin the rhetoric of ideologues and politicians and (2) pervade and subvert even the rationalistic discourse of planning and regional development policy." (Shields 1991:6).

To achieve its aims, the paper is structured as follows: first, it positions LRT at the interface of broad urban development agendas linked to city boosterism and cultural geographic understandings of space as socially constructed. Second, methods of review and analysis are explained. Third, existing empirical evidence from a range of medium- and large-cities, as well as wider urban areas, mainly in the developed world, is evaluated. Finally, the paper concludes key findings and directions for future research.

\subsection{Boosting City Image and Quality}


According to Banister and Berechman (2001:211), "image building is key to the revitalisation of central areas and in maintaining strong city centres". High quality transport infrastructure can assist image building through the materialisation of ideas and perceptions held by social actors, as well as re-shaping physical spaces, for instance, through improved accessibility and connectivity (Vuchic 1999). Niedzielski and Malecki (2001:1414), for example, indicate that rail-based systems have often been seen as "symbol[s] of development, progress, and identity", while Nolte and Yacobi (2015:33) demonstrate the way in which light rail has been central to reconstruction of Jerusalem as a modern and dynamic city by means of "improving the city's transportation" and "restoring the city's charm and appeal". Image building is also a key strategy associated with city marketing or "boosterism" to help cities develop a more competitive edge (Newman and Thornley 1995; McLellan and Collins 2014; Paget-Seekins 2015), not only economically, but socially and politically (Hubbard 2008; McCann 2002; Sari 2015). A city's ability to compete in 'nonconventional' ways may contribute significantly to its image and reputation, further stimulating economic growth through its ability to attract more people and commerce into the city. High quality transport infrastructure can help to facilitate these processes (Banister and Berechman 2001).

Public transit is increasingly linked to institutional discourses on sustainable mobility (Hickman et al. 2013), sustainable cities (Ferbrache and Knowles 2016), and social equity/inclusivity (Farmer 2011), each of which projects ideas that cities should be attractive and high quality places to live. Mulliner and Maliene (2011), argue that people's perceptions of the quality of their environment is central for generating sustainable cities that enhance the attractiveness of an urban area. In this way, image and quality are interlinked. Urban design, including plans for public transit, is at the forefront of cities' efforts to increase the quality of life of their inhabitants (DETR 2000; ODPM 2005; Urban Task Force 1999). For example, Thomson (1978:322) argues that:

The choice of transport strategy is not simply a calculation of cost-effectiveness. It is also a choice of way of life. Moreover, it is a choice which may affect different sections of the population very differently.

In the United States (US), in 2010, revisions to new federally-funded transit projects emphasised criteria that promoted 'liveability' over cost-effectiveness (Vincent 2010). While cities have sought to tackle traffic congestion, accessibility and environmental impacts as key objectives of light rail development (Babalik-Sutcliffe 2002), increasingly, wider impacts in terms of economic growth and the creation of sustainable and liveable cities are part of broader development agendas (Banister and Berechman 2001; DETR and CABE 2000; ODPM 2005; Urban Task Force 1999; Vuchic 1999). However, light rail, often implemented as a neoliberal project (Grengs 2005; Paget-Seekins 2015), has not always achieved its objectives (Babalik 2000; Babalik-Sutcliffe 2002; Farmer 2011; Hass-Klau et al. 2004), often because broader goals of social equity and economic growth are not compatible (Grengs 2005). However, additional or unintended benefits, such as boosting city 
prestige on the international stage, may occur and help to raise a city's 'world-class status' (PagetSeekins 2015).

In this paper, image and quality enhancement are considered as part of broader urban development goals towards city boosterism - i.e. improving image and quality to help boost the status of a city as sustainable, socially equitable, and liveable. Social actors are central to this process: as designers and planners of these urban areas, and as individuals or social groups valuing the city. Image and quality are problematic categories as their meanings and application rely on subjective assessments. How we measure them is also problematic, particularly those based on subjective valuations for, after all:

The imaginary (thoughts, fantasies, and desires) is a fertile source of all sorts of possible spatial worlds that can prefigure - albeit incoherently - all manner of different discourses, power relations, social relations, institutional structures and material practices. (Jensen and Richardson 2004:65).

A cultural geographic perspective and conceptualisation of space as socially constructed and relational, helps us to analyse the place-making relationship between light rail development and city boosterism, and to make sense of what happens to city image when light rail is introduced.

\subsection{Place-making}

Following Lefebvre's (1991) argument that "space is not a thing but rather a set of relations between things", we approach cities as socially constructed spaces and also draw on Massey's (2005) relative understandings of space to suggest that cities are heterogeneous assemblages of movements, materials and ideas that are integral to their production and reproduction. She argues that "identities/entities, the relations 'between' them, and the spatiality which is part of them, are all co-constitutive." (p.10). Jensen (2013:6) provides specific reference to the types of 'identities/entities' that influence the production of urban spaces: "planning, design, architecture, governance systems, technological networks as well as by the social interactions, cultural meanings and the production of social order". From this perspective, transport becomes an agent in the production of space; a conceptual contrast from more traditional views of transport as something that moves across a surface or within a contained space (Cresswell and Merriman 2010; Knowles 2006).

Olesen and Lassen (2016) provide a unique insight to light rail as agent. They draw on Appadurai's (1990) conception of 'scapes' to propose 'light rail scapes' as an heterogeneous mix of "trains, tracks, stations, masts, stops, train designs and colors" as well as "politics, discourses and metaphors" (p.374). Appadurai indicates that "these are not objectively given relations which look the same from every angle of vision, but rather that they are deeply perspectival constructs, inflected very much by the historical, linguistic and political situatedness of different sorts of actors" (1990:296). This is the means through which Jensen and Richardson (2004), above, argue that imaginary is a fertile source of possible spatial worlds. Thus, light rail is represented as an 
assemblage, and simultaneously part of a wider assemblage that produces city spaces. Our paper is underpinned by such conceptual framing though, where relevant, our analysis pinpoints particular features or elements of light rail, such as vehicle design, to which social actors attach specific meaning.

Typically, geographers have defined place more specifically than space, as sets of relations imbued with meaning, purpose and identity (Entrikin 1991; Lefebvre 1991; Massey 2005; ). The action of place-making thus refers to a process through which spaces take on cultural meanings and significations as ascribed by social actors. For example, a pedestrianised square may represent safety or exclusion depending on the geographical and temporal context as well as who is defining that place (Appadurai 1990). Bringing together ideas and images with material spaces, Shields (1991:6) indicates how they might fit together: "The cultural context of images and myths adds a socially constructed level of meaning to the genus loci, the classics' 'unique sense of place', said to derive from the forms of the physical environment in a given site." From this perspective, transport is not only the "material 'stuff' that makes up place" (Sheller and Urry 2006:216), but the meanings attached to it become associated with, and influential, in place-making processes that ascribe significance to the wider spaces in which light rail is developed. While transport geographies have taken up cultural understandings in this way (Cresswell and Merriman 2010; Shaw and Hesse 2010; Shaw and Sidaway 2011), light rail has rarely been analysed from such perspectives.

From a city-making perspective, Frug (2001) demonstrates how dominant city infrastructures (of which transport is a part) are given meaning, and which in turn produce identities through the values and meanings that social agents have about the city. Olesen and Lassen (2016) demonstrate this process with light rail, particularly focusing on ex-ante visions and discourses, and the extent to which these are materialised in the city. They focus less on ex-post impacts of image and city quality, which rely both on ideas and symbolic meanings given to light rail, in relation to (and impacting on) the city (DETR 2000; Van den Berg et al. 1999), and the actual material transformations that follow light rail development. Both the ideas and the material elements are important in city-making (Frug 2001; Jensen 2013; Lefebvre 1991). In terms of the former, Shields (1991) argues that the creation of 'place images' is one way in which places come to have specific meanings. For example, developing high quality transport infrastructure that is perceived to be modern and 'sexy' as light rail (Hensher 2016) may contribute to a 'place image' of the city as modern and innovative, thus helping to boost perceptions of the quality of the city as well as its image. In the latter case, the transformation of physical spaces can be understood as an impact, for as Clark (1958) argues, transport is the "maker and breaker of cities", as urban development patterns and urban spatial structures are altered by successive transport technologies and different transport modes. In addition, transport infrastructure has been incorporated into land use planning initiatives such as transit oriented development (TOD) as a catalyst for physical urban transformations (Cervero 1998). It is these two elements: symbolic meanings and significance applied to light rail image and the city, on the one hand; and significance of material 
transformations in the urban setting, on the other, that we distinguish in this paper. Furthermore, while we focus on ex-post evidence, it is sometimes difficult to separate ex-ante from ex-post as discourses about light rail can be materialised and, subsequently, materialities reproduce discourses (Jensen and Richardson 2004; Lefebvre 1991), as Olesen and Lassen (2016) demonstrate.

\subsection{Methods}

To assess impacts of light rail on city image and quality, our analysis is based on a detailed and critical review of English-language light rail literature. We examined peer-reviewed and non-peerreviewed sources from published and unpublished research, including academic work, Impact Studies and consultancy reports (up to March 2014). Data informing this paper emerged as part of a larger project synthesising evidence on wider economic impacts of light rail on cities across the globe (Citation 1; Citation 2) ${ }^{1}$. Post-2014 academic publications have been included in this paper.

van Wee and Rietveld (2013) indicate that while transport infrastructure may increase the image, quality and prestige of a city, measuring these subjective elements is extremely difficult. Not only are terms such as 'quality' and 'image' extremely vague, but valuation of characteristics attributed to these categories (i.e. the strength of their impact) are also highly subjective and will vary across different social actors at different times (Jensen and Richardson 2004). This pertains to the continual nature of place-making as always under construction (Massey 2005). We were able to deal with these methodological problems to varying levels of satisfaction. For example, quality and image were categories that emerged in our analysis of the wider economic impacts as it became clear that links were made between light rail and people's ideas about the city. Coding enabled us to break down these categories further into ideas about light rail, such as 'modern', 'prestigious' and a reflection of 'cultural identity'. The notion of quality was found to be linked to discourses on social equity (i.e. quality of life and mobility available to different groups within a city) and environmental effects, and could be traced with reference to improvements or reductions in levels of quality.

Evidence tended to be based on various stakeholders' subjective valuations, while a few evaluations were based on surveyed opinions. Where possible, we have identified stakeholders (e.g. transport planners or operators, urban planners, developers or academic researchers) to

\footnotetext{
${ }^{1}$ Image-building and place-making occur at different geographical scales and locations from improvements at individual street level to boosting the image of a city, as a whole. Impacts may be identified in city centres as well as non-central areas While we (and many of the social actors remarking on light rail image impacts in this paper) refer to cities generally, wider impacts of light rail have been identified in city centres as well as non-central areas, which may includinge regeneration zones (sometimes including those-on reclaimed land), and . Wider economic impacts also affect impacting larger urban/city regions. While certainWhile some impacts, such as land capitalisation, are more common demonstrate that light rail often impacts to a greater extent-in the immediate vicinity of stations (e.g. within 400metres), it is not always possible to discern effects in relation to measurable distance. Light rail infrastructure can be a key element in boosting the image of the eity, as a whole. Given the material the authors are working with, evidence is not organised according to scale in this paper. However, this does not seek to undervalue the way that image-building and place-making may vary at different scales.
} 
provide context and discern significance from their valuations. However, this was not possible in all cases, for where anecdotal evidence was included, it was rarely the focal point of the research and, therefore, identification of the particular stakeholder making a claim was not always given significance. In addition, there was often a lack of context and detail to explain the meanings that stakeholders applied to the qualitative terms they used. For this reason, 'image' and 'quality' are not pre-defined in this paper, but expressed in the way that social actors employ the terms.

Similarly, we sought to identify the period in which light rail was assessed for analysis during a construction phase is likely to capture less positive ideas, partly due to disruption around usual activities and access routes in areas concerned (Lawless and Gore 1999), or from projects that exceed their time and costing estimates (McKie 2014). In contrast, research carried out many years after construction may overlook earlier opinions. This provides an important finding in itself, that further research is required, for example to gain a more representative and/or longitudinal study to trace the variation and evolution of valuation of impacts over time.

The following section synthesises the results of the critical literature review, first presenting ideas and perceptions of light rail, and their meanings towards city boosterism, and second, material transformations that have impacted city image and quality.

\subsection{A modern sense of place}

Within existing light rail literature, 'modern' is both a common descriptor of light rail, and of those cities with light rail infrastructure. City planners in Edmonton, Canada, for example, described their light rail "as progressive, modern, cosmopolitan" (Knowles 2000:12), while Jerusalem's light rail is valued and promoted as a means of modernisation, innovation and improvement by the Municipality of Jerusalem (Nolte and Yacobi 2015). Examining first, the image of light rail itself, the idea of a modern form of transit refers both to its technological sophistication (Boschken 2003) and its appearance. Stakeholders have captured this through a range of evocative adjectives, including "sexy" (Development Consultant, Vancouver, Canada), "buzzy, energetic, exciting" (Chief Executive, Light Rail Operating Company, Manchester, UK) (Knowles 2000:12), and "cool and sleek" (a local business owner in Croydon, UK) (SDG 2005:61). These impressions construct aesthetically pleasing systems that symbolise an up-to-date mode of transport in city centres, as demonstrated in Figure 1. In the literature, anecdotal evidence such as this, is often insufficiently contextualised or explained in adequate depth to understand stakeholders' choice of words, or exactly how they are used. Hass-Klau et al. (2003:15) identified this as a problem during research, for "None of those interviewed gave a clear or consistent definition of the size or weight" of such attributes. Furthermore, anecdotal evidence rarely provides insight to views of multiple stakeholders, thus failing to capture the range of perceptions and feelings about a particular light rail system. While further research is necessary to better understand the depth and range of subjectivities relating to light rail, we can discern a general impression of the way in which light rail is valued in specific locations. Another way in which we might learn a little more, is via literature that compares light rail with other forms of transit, notably bus rapid transit (BRT). 


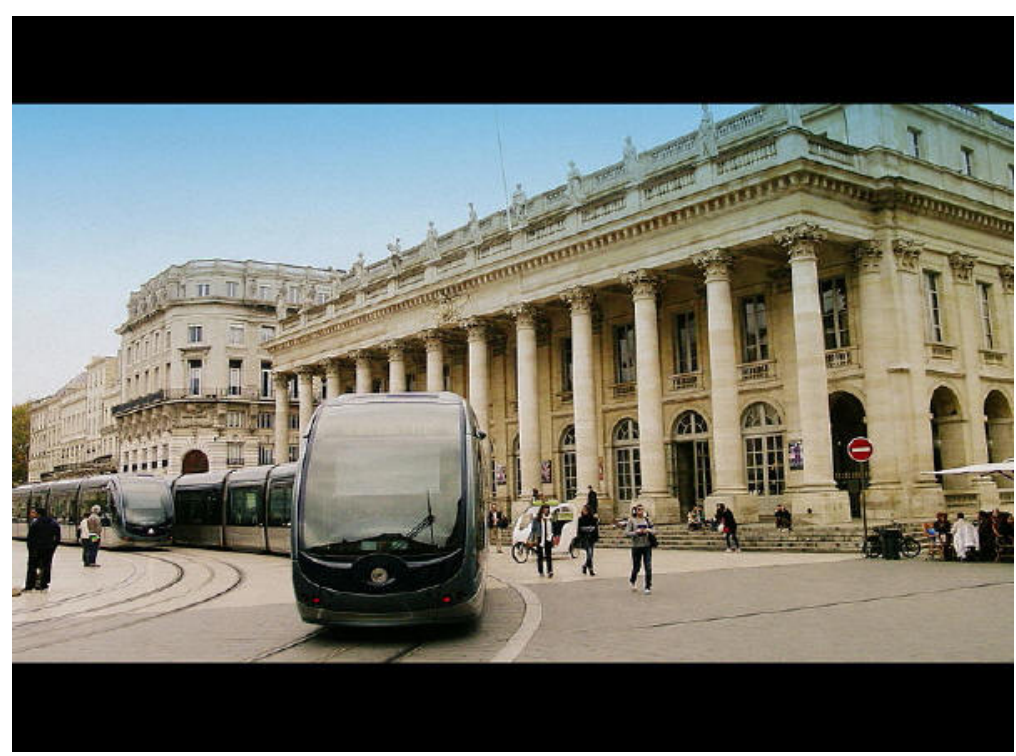

Figure 1: The 'Bordeaux Transformation': wireless trams create a sleek, modern image in the city centre. Source: Wikimedia Commons: Marie-Michèle Mailhot

Literature drawing comparisons between light rail and BRT often takes as its starting point the notion of a "mythical allure" about light rail that buses do not possess (de Bruijn and Veeneman 2009; Weinstock et al. 2011). "Mythical allure" refers to the way that rail, rather than bus transit, appears to attract more interest from various social actors (the media, stakeholders, urban planners and residents, for example) (Olesen and Lassen 2016). It is linked to Hensher's (2016) concept of "emotional ideology" and the view that "trains are sexy and buses are boring" (Hensher 2016:289). Such impressions can be seen in decision-making and urban planning (Edwards and Mackett 1996; Hidalgo and Gutiérrez 2013), and lead to suggestions for design strategies, as recommended by Hodgson et al. (2013:159): "One way of generating ridership numbers for buses similar to light rail would be to make the bus look and feel like a tram" (see also Cain and Flynn 2013).

Ex-ante discourses often look to cities with existing LRT for evidence, though there are divergent results. For example, users of the Midland Metro, Birmingham, UK, perceived light rail as "clean, fast and stylish" compared to the "antiquated, slow, dirty and uncomfortable" bus service (SDG 2005:55). More recent research from Australia and other countries, indicates that BRT can match the image quality of light rail, particularly where customers have direct experience of BRT (Cain and Flynn 2013; Hensher and Mulley 2015; Nikitas and Karlsson 2015). To begin making sense of the different impacts, we need to understand more context, for example, the specific type of transit systems in operation, though similar systems in different cities will have quite different impacts. For example, Cain and Flynn (2013), indicate that the image of the urban areas surrounding transit infrastructure may have greater influence on aggregate perceptions of image quality than the system itself. While we can draw out particular evidence of LRT versus BRT in some places, and a sense of different images being created in different cities (Edwards and 
Mackett 1996; Hensher 2016), Hass-Klau et al. (2003) suggest that comparisons between light rail and bus can be flawed and incomplete and may not reveal more than analysis of light rail alone.

One example where light rail has been used to enhance the image and quality of a city to a large extent, is in Salford Quays, Greater Manchester. Roger Tym \& Partners Ltd (1996) noted the expectation (in 1996) that the Metrolink extension to Salford Quays would help improve both the image and quality of the largely derelict dockside area. High crime levels, perceived lack of spaces to eat, shop and spend time, and a perception that female staff were at risk when walking alone, were anticipated to be overcome with the arrival of Metrolink. Salford Quays has been heralded as a model of a post-industrial waterfront with mixed-land use developments, landscaping and pedestrianised areas, and light rail was used to attract investment and revitalise the area (Knowles and Ferbrache 2015). Similar successful examples could be drawn from London Docklands, Croydon and Sunderland, UK; and Ørestad New Town, Copenhagen, Denmark (Hass-Klau et al. 2004; Knowles 2012; Knowles and Ferbrache 2014), where light rail has helped to boost image and quality of city areas, potentially further fuelling the idea of a "mythical allure". However, it is difficult to isolate the impact of light rail on place-making from other changes to the area such as the development of housing, pedestrianised areas, business and leisure facilities.

\subsection{Promoting the city}

The image of light rail as the modern form of public transit has contributed to city boosterism as a city's reputation and prestige has been raised alongside development of light rail. For example, with a light rail system, "City fathers see Edmonton in the big league" (City Council Transportation Officers, Edmonton, Canada), "Big league look. Small city with a big city image" (Business Association, Edmonton) (Knowles 2000:12), while key informants in Vancouver believed that "Something as sexy as SkyTrain puts the city [Vancouver] into the senior league" (Development Consultant, Vancouver) (Knowles 2000:12) (Figure 2). Edmonton and Vancouver are not typically considered as world cities, rather they are 'mid-sized cities' (McLellan and Collins 2014), where city leaders have sought to enhance their profile with modern transit systems ${ }^{2}$. In Dallas, an expectation of light rail was its perceived ability to boost the city's image as a 'world city' (Edwards and Mackett 1996). In the UK, Croydon business owners felt that light rail created an impression of the London borough "going places" (SDG 2005:5), and creating a "cutting edge" place (SDG 2005:61).

\footnotetext{
${ }^{2}$ Vancouver is regarded as a successful example of TOD, whereby developments along the transit line have led to growth. Hence, the idea of Vancouver raising its profile cannot be isolated around the role of light rail.
} 


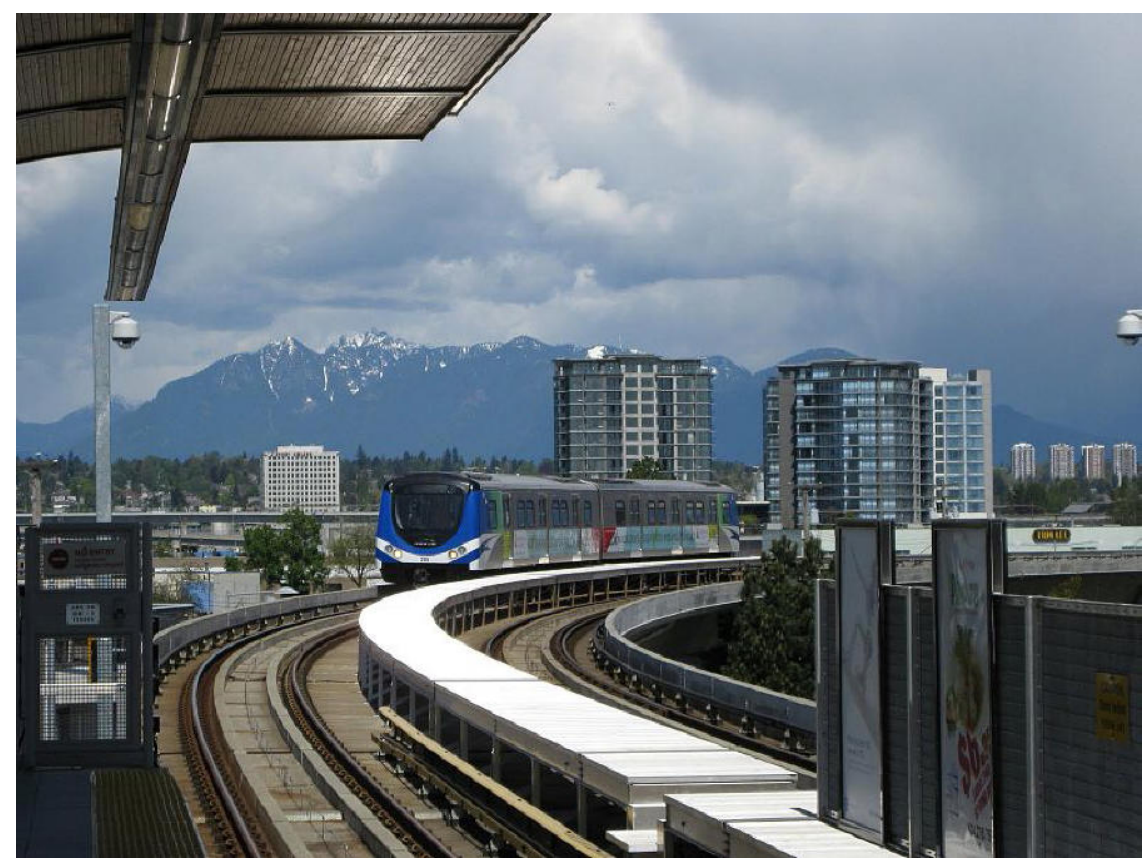

Figure 2: Vancouver SkyTrain helped to raise the profile of the city. Source: Wikimedia Commons: Haizhebear

These examples demonstrate a sense of moving forward: of progression and development. The language of modernity is implied with the idea of progressing upwards in urban/city status rankings. McLellan and Collins (2014) elaborate the relationship between a high quality transit system and world-class city status where there is a strong perception that cities with bus systems remain second tier cities, implying that those with some sort of rail-based system gain a competitive edge. It is recognised by academics and urban planners that a city with a leading reputation can sometimes influence locational decisions of potential businesses, visitors and residents, thus drawing inward investment and contributing to overall economic growth (HassKlau et al. 2004). Hass-Klau et al. (2004) remain cautious, however, indicating that "the role played by the LRT line is impossible to judge with any precision" (p.25). While we acknowledge this, evidence generally suggests light rail as an agent in broader development agendas.

In some places, surveys have been conducted to gain more insight into the way people value their light rail system. According to Walmsley and Perrett (1992), Nantes' (France) inhabitants perceived that the tramway had improved the city's image. In Newcastle, UK, a survey by the City Council found that the Metro logo, a distinct black ' $\mathrm{M}$ ' on a yellow background, as seen in Figure 3, was recognised by residents as an "iconic symbol of the city" (Assistant Head City Council Strategic Planning and Transportation, Newcastle) (Knowles 2012:12). This latter example indicates how city stakeholders can boost the image of light rail (and the city) by encouraging local and international recognition (Development Agency, Manchester, in Knowles 2000:12; and Oscar Faber 2002). Frug (2001) argues that a dominant characteristic of city-making strategies (by policy-makers and public officials), is to promote key elements of the city as landmarks. Light rail helps to fulfil this role in a number of ways. Light rail images or symbols ('M', for example) have been used to promote the city to tourists, for example in Newcastle (SDG 2005), and Jerusalem where, in one advertisement 
by the Municipality, light rail was juxtaposed with other images of modernity to attract athletes for a running race (Nolte and Yacobi 2015). Elsewhere, light rail has helped boost the profile of cities through distinguishing transport schemes, for example, in Canada where "Streetcars are a symbol of Toronto like San Francisco cable cars" (Transit Consultants, Toronto, Canada) (Knowles 2000:12). In Newcastle, the City Council's Assistant Head of Strategic Planning and Transportation, claimed that the Metro has "Equivalent status to the Tyne Bridge" (Knowles 2000:12).

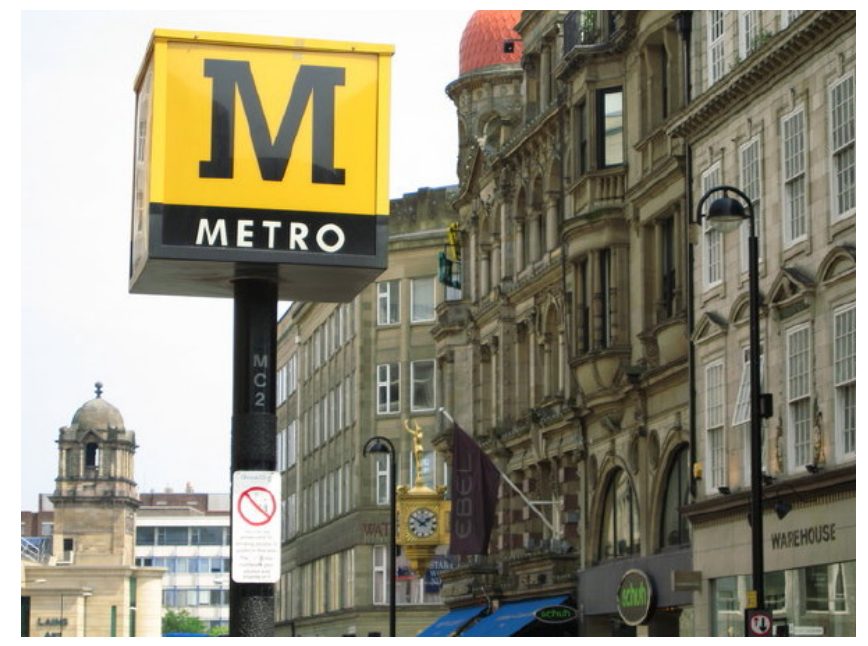

Figure 3: The iconic ' $\mathrm{M}$ ' logo of the Tyne and Wear Metro. Source: Wikimedia Commons: wfmillar

There is evidence to suggest that some cities with successful light rail systems have been recognised on the international stage for their transport infrastructure. Grenoble, one of the first French cities to install a modern tram system, is often recognised as a role model for other cities (Boquet 2015). A chief light rail engineer in Bergen, Norway, explained how Grenoble's system "...was a tremendous success, not just as a transport project, but as a city development project, because it was really pretty. It had a very little [sic], nice amenities in the centre of town, bicycle paths and artwork and fountains and all those things. So, some people had seen that, and we used that to try to sell the system [in Bergen]" (Olesen and Lassen 2016:376). Decision makers in Bergen also visited Montpellier, France, describing it as "a very impressive and elegant system" (Olesen 2014:13). Similarly, on seeing the véhicule automatique léger (automated VAL) metro in Lille, France, one City Council leader in the UK claimed "his city had to have one, because it contributed to his image of a major European city" (Edwards and Mackett 1996:232). While these comments pertain to expectations for light rail development in cities without such infrastructure, they are based on valuations of systems elsewhere and demonstrate the international prestige associated with particular light rail in particular cities. This forms an important part of the way in which transport infrastructure ideas are transferred between cities across the globe (Wood 2015).

Ex-post evidence captures a similar sense of prestige. A local business owner in Croydon remarked: "I'm from Yorkshire, and even people I know up there, when you mention Croydon, they go 'they've got trams now.'" (SDG 2005:61). Other business owners in Croydon, and stakeholders in Manchester expressed city boosterism in terms of "a more European feeling" in the city as a result 
of light rail (Development Agency, Manchester) (Knowles 2000:12; \& Oscar Faber 2002). These place-making ideas draw on light rail in France, which are often celebrated as some of the best global examples (Hass-Klau et al. 2004; Olesen 2014) and strongly associated with landscape planning, pedestrianisation and outdoor spaces for cafes, restaurants and socialising (Boquet 2015). Evoking this idealised 'European' image helps to distinguish places from their counterparts in the UK. Thus, the esteem with which some light rail systems are valued as "a distinguishing feature" (Edmonton) (McLellan and Collins 2014:209) can be significant to facilitate city recognition at national and international level. How certain cities becomes recognised over others, is an important question to better understand the transferability of ideas and impacts.

\subsection{Cultural identity}

According to Olesen and Lassen (2016), the influential relationship between light rail and city image is two-directional: light rail shapes the city, but key city attributes also shape the image of light rail. This is particularly evident in French cities. Burgundy-coloured trams in Dijon, for example, evoke the regional Burgundy wines, in Reims, trams are designed with 'faces' shaped like a glass of Champagne (Boquet 2015), while the tram design in coastal city Marseilles is inspired by the bow of a ship. In Angers, the tram is considered an emblem of the city "famous for agriculture and flowers" (Olesen and Lassen 2016:379) and this is represented through an interior design with ceiling and seats decorated with flowers. In addition, plans to direct light rail through the historic centre of Angers relied on an expensive advanced technology system to provide a power supply via a third line between the tracks, rather than introduce overhead wires to an architecturally sensitive area. Not only does this demonstrate how light rail is adapted to the style of the existing city, but it also promotes more technologically sophisticated infrastructure than in cities with overhead wires. While Olesen and Lassen (2016) identify Angers as an extreme example, this and other French examples demonstrate how light rail designs have been carefully crafted to replicate the culture and character of the city, and sometimes its wider region. Light rail may therefore reinforce a city's sense of identity where "identity and uniqueness are crucial elements in a city's attractiveness" (Mulliner and Maliene 2011:149; Frug 2001; Van den Berg et al. 1999). These examples highlight the close connection and two-way place-making relationship between light rail and city as both constitute the other's identity to reinforce a particular and carefully constructed sense of place.

\subsection{Social equity}

Light rail as an agent in place-making, can construct places of social equity (in terms of providing access for more disadvantaged groups in a city) or places of social threat (i.e. to certain groups excluded from light rail) (Farmer 2011). Place-making in this sense relates to valuations about quality of life in the city is linked with wider goals for sustainable and liveable cities. Nolte and Yacobi (2015) demonstrate that light rail has provided a discourse or physical means that has united political divisions within a city. They claim that "Jerusalem and light rail are presented as the embodiment of modern" (Nolte and Yacobi 2015:33) with the tram system bringing benefits to all residents of the city in terms of attaining "societal (modernist) goals, such as residential 
amenity, economic efficiency, social equity, or environmental sustainability". In this way, it has generated a sense of place that "unites" the different claims to the city. This optimistic vision is built around ideas of light rail as modern, progressive (inclusive) and innovative. In other examples, a Bergen politician referred to light rail as "more than transportation", with "a remodelling of the mobility hierarchy in the city... a catalyst for a new urban lifestyle" (Olesen 2014:13). Accordingly, Bordeaux's light rail was constructed "to modernize and to increase the living standards in neighborhoods" (Sari 2015:233) and reduce social-inequalities between the left and right banks of the Garonne river by providing a fixed transit connection between them (Sari 2015). These impacts relate to the image of a more equitable society and city, and thus more broadly to the perceived quality of life within the city. However, these impacts do not exist for light rail alone, they also apply to BRT (Alpkokin and Ergun 2012).

In other cities, such as Los Angeles and New Orleans, US, light rail reproduced social inequalities by providing a transit system more accessible to middle-income residents than lower-income residents (Cresswell 2006; Hutchinson 2000). For these residents, light rail impacts are likely to be valued very differently, and as they form important parts of a city assemblage, the way residents identify with the city will impacts its perceived quality and liveability (Mulliner and Maliene 2011). Recognising these place-making impacts of light rail carry significance for future urban and transit planning in cities concerning who is and who is not expected to use transit, as well as who actually uses it.

\subsection{Environmental Quality}

Social construction of light rail as an environmental benefit was found to connect LRT to ideas of quality and city boosterism, drawing much on the language of innovation, progress and modernity. This is often expressed in terms of tackling key issues, or achieving specific goals within the city. Stakeholders for example, claim that Vancouver's SkyTrain "looks progressive - doing something about road congestion" (Academic researcher, Vancouver) (Knowles 2000:12). Experts in Newcastle and Sunderland, UK, identify the same form of progressiveness where light rail represents the city's proactive investment to tackle traffic-related problems (Transport Authority Directors of Planning and Route Extension) (Knowles 2000:12). In these examples, the value of light rail is strongly linked to environmental and sustainable mobility discourses designed to enhance cities and deal with problems such as congestion and pollution. This is grounded in the view that light rail provides an alternative public mode of transport for private vehicles users, thus reducing the number of polluting vehicles on the road (Babalik-Sutcliffe 2002, Knowles 2006, Olesen 2014).

In some places, a key objective of new light rail schemes has been improvement of environmental quality through noise and pollution reduction. However, Babalik-Sutcliffe (2002) found that none of eight new light rail systems across the USA, UK and Canada, achieved their environmental objectives, suggesting that this assumption has been overestimated by stakeholders (Hass-Klau et al. 2004, Mackett and Edwards 1998). Evidence also exists of the environmental performance of 
different transit systems: when compared with buses, light rail has been found to generate less noise and vibration, but is roughly equal in terms of $\mathrm{CO}_{2}$ and others emissions (Knowles 1992; Hodgson et al. 2013). A critical finding for environmental quality is the comparison between light rail and private vehicles, and in this instance, it generally performs better.

A further consideration of environmental quality relates to the built environment and visibility of light rail. Head of Planning for the tri-Met Transit Agency in Portland, Oregon, US, claims that the image of the city has been enhanced because "Light rail operates at the surface and offers visibility" (Bernick and Cervero 1997:49). This has been accentuated in Vancouver, London Docklands and Ørestad, Copenhagen, where sections of light rail have been raised on elevated tracks to enhance iconic visual status (Figure 4) (Knowles 2012; SDG 2005). Yet, the iconic impacts do not necessarily include the supporting infrastructure of light rail, and the extent to which visibility is valued depends on the micro-level geography of the city. For example, in architecturally-rich city centres, or on historical features such as the Loire Bridge (Tours), concern that overhead wires may damage or detract from architectural quality have sometimes been addressed by using APS ground power supplies, rather than visible overhead wires, as in Bordeaux, Angers and Tours, to name a few cities (Groneck and Schwandl 2014; Olesen 2014; Sari 2015). This is referred to as the 'Bordeaux Transformation' (Figure 1). In other places, Besançon, France, for example, light rail does not traverse the central area for aesthetic, as well as financial, reasons. Similarly, light rail in Germany has been described as "nearly pollution free" (Hass-Klau et al. 2003:78) due to many lines constructed underground to enable pedestrianisation at street level. These choices contribute to the aesthetic qualities of places produced in connection with light rail development, however, not all cities are able to maximise such aesthetic qualities due to existing design structure of the city, or costs involved. The aesthetic qualities also change considerably through construction to operational phases, and it is during construction and early operation periods that we identified more negative impacts of light rail on city image.

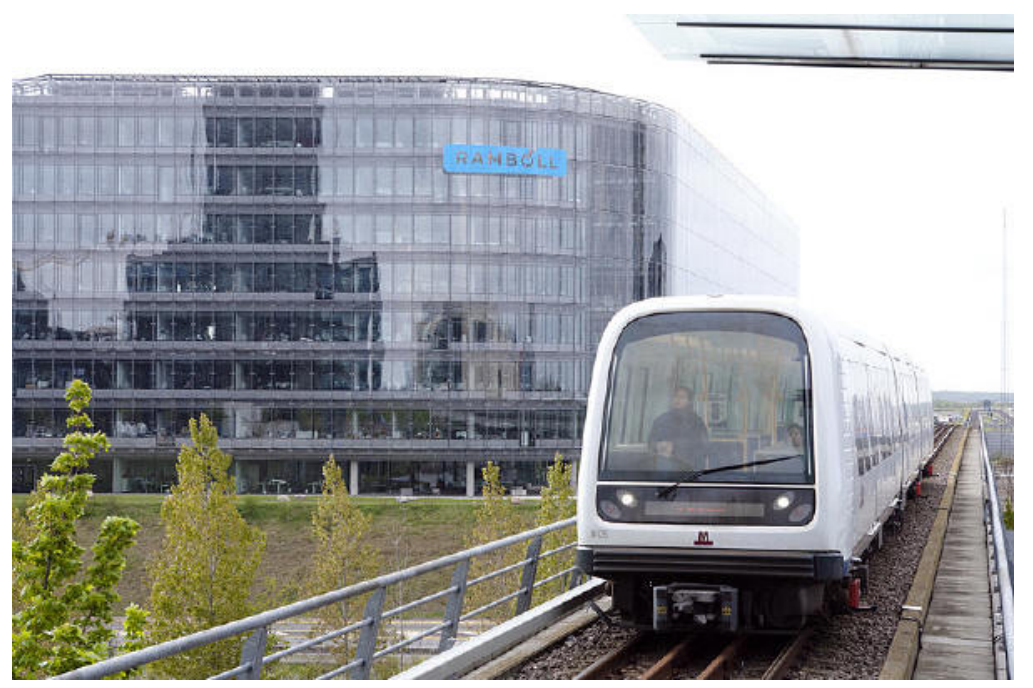

Figure 4: Copenhagen Metro on elevated tracks in front of Rambøll Engineering, Ørestad City. Source: Wikimedia Commons: Mdann52talk to me! 


\subsection{Negative Image}

In broad terms, light rail has an overwhelmingly positive image in the literature examined, though this could be a potential misrepresentation, as the majority of evidence emerges from literature addressing research questions unrelated to image. However, Sheffield and parts of Greater Manchester provide two key examples where light rail was, for some time, perceived more negatively. In both cases, disruption characterised light rail during much of its construction phase when dust, noise and road closure altered usual access and mobility in urban centres. In addition, street closures were needed for replacement/relocation of underground utility pipes and wiring, and subsequent construction of light rail tracks, overhead wiring and stations/stops (Dabinett et al. 1999; Hass-Klau et al. 2004; SDG 2005). Knowles has demonstrated, however, that where a new light rail system can use existing tracks, there may be less disruption than where new tracks are laid. For example, Manchester Metrolink Phase 1 (Bury/Manchester/Altrincham) had a strongly positive image as it secured above forecast traffic and an unexpectedly large modal switch from cars: more than 20 per cent of passengers previously used cars for those journeys (Knowles 1996). Phase 2 was less successful and did not achieve traffic forecasts. Parts of Phase 3 had negative image during construction due to major disruption of car, lorry and bus traffic especially on the onstreet Ashton line particularly through Droylsden town centre, and also on the Oldham and Rochdale town centre on-street sections. Once Metrolink opened in Oldham town centre, it has a strongly positive image along most of its Manchester/Oldham/Rochdale line, indicating that the period of negativity associated with disruption can be short lived and, even in Sheffield, where early Impact Studies demonstrated a strongly negative image of two of the three on-street routes (Dabinett et al. 1999), later evidence indicated a positive image (Crocker et al. 2000). In other places, a positive image may be boosted with proactive efforts to address key issues. For example, in Vancouver (Babalik 2000) and Saarbrücken, Germany. Hass-Klau et al. (2003), note that concerns about noise levels from light rail were addressed, in the former city, with noise barriers built along the corridor.

These negative images of light rail demonstrate the dynamic element of quality assessment, particularly from negative to positive impressions. There is less evidence of negative image within the literature, and these tend to emerge from studies carried out during, or soon after construction. Nevertheless, they have specific geographical and temporal impact on the image of the city (Hass-Klau et al. 2004), though for research, longitudinal studies are better suited to capture the dynamic elements of image association.

Images of light rail take on meaning that become part of place-making processes. In many cases, images of light rail spillover to influence images of a city, and in some cases, such as Angers, the wider region itself. Recognising these place-making strategies of 'railscapes', Cresswell (2006) argues that this has often escaped planners and developers who could take more advantage and use infrastructure as a catalyst for development and transformation to materialise such symbolic images of the city through marketing and urban planning, for example. This corresponds with 
boosting city competitiveness (Hubbard 2008). The paper next examines more material placemaking impacts of light rail.

\subsection{Material place-making}

One of the principal motivations for implementing or expanding light rail infrastructure is to use it as a spatial planning tool to achieve wider urban development goals and foster sociable and healthy cities that boast a higher quality of life (Babalik-Sutcliffe 2002; King and Fischer 2016, McLellan and Collins 2014, Mulliner and Maliene 2011, Sari 2015). Place-making strategies have formed the basic planning principles towards regenerating quality city environments in many US, and continental European cities, as well as elsewhere. In the US, particularly, and Asia, this is referred to as TOD, a process that places public transit at the heart of plans to develop highdensity and mixed-land use forms that are considered sustainable and more socially equitable approaches to urban development (Arrington 2009; Hass-Klau et al. 2004; Loo et al. 2010; Sari 2015). Light rail has often been heralded as a catalyst for regeneration and quality improvement in this way (Arrington 2009; Cervero 1998; Dorsey and Mulder 2013), however, it is also recognised that such schemes rely upon high-quality organisation and a long-term planning vision (Priemus and Konings 2001), and are not created by transport alone (Lavery and Kanaroglou 2012).

In Europe, a more common term referring to similar processes is spatial planning (King and Fischer 2016; Olesen 2014) where, for example, a range of initiatives have emphasised the need to use public transit to transform cities "from being noisy, polluted places into vibrant, people centred environments as well as facilitating the widespread re-allocation of street space to PT [public transport], cycling and walking" (CFIT 2001:24). According to King and Fischer (2016:2) "spatial planning is a deliberate effort by local governments or territorially-based policy communities to take place-shaping seriously." Within western Europe, particularly, the idea of "The Grenoble Effect" provides a visionary model that has been widely replicated in place-making initiatives, especially in many French urban areas.

\subsubsection{The Grenoble Effect}

The majority of light rail success stories emerge from examples where transport and planning initiatives are developed in conjunction with one another. For example, Olesen and Lassen (2016) explain that Bergen's light rail system was transformed into an urban development project and new brand for the city, even before it was given political acceptance. Grenoble is often held up as an ideal model, in this sense, and its reputation is captured in the phrase 'The Grenoble Effect' (Shaw and Docherty 2014). This model captures the way in which light rail was successfully integrated with wider urban development plans to transform the city centre into an aesthetically appealing place where pedestrianisation and public squares replaced private vehicle mobility spaces; wide boulevards were transformed from car thoroughfares and parking, to areas specifically designated for public transport (trams) and pedestrians. With these achievements, Grenoble is recognised for having created a high quality and more attractive environment, as illustrated in Figure 5 (Walmsley \& Perrett 1992). The significance of this place-making strategy is 
demonstrated through replication of the 'Grenoble Effect' model throughout many French cities, including Bordeaux, Lyon, Montpellier, Nice and Rouen (Boquet 2015; Hass-Klau et al. 2004), in Bergen (Olesen 2014), and in future plans for cities such as Oxford (URBED 2014).

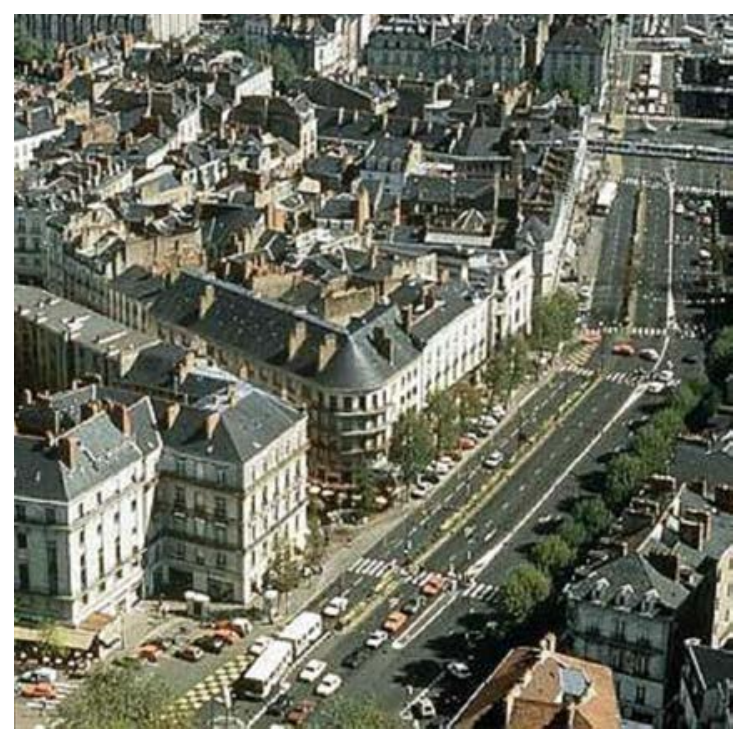

Before

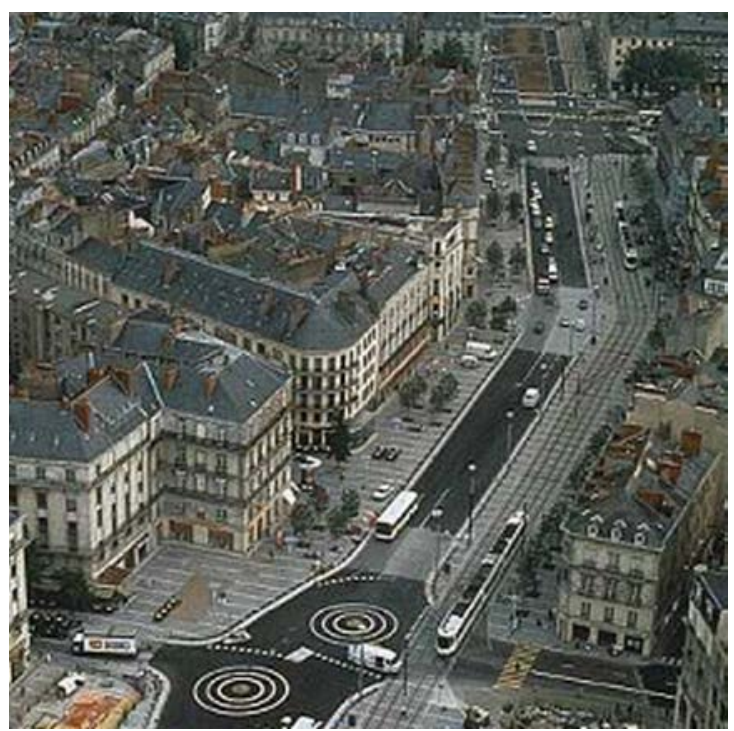

After

Figure 5: The 'Grenoble Effect': Landscape changes before and after implementation of light rail. Source: Pitrel, 2008

Capturing the power of the "Grenoble Effect" for place-making, Shaw and Docherty (2014) described the 2014 city centre of Nice as unrecognisable from its earlier design, to demonstrate it as "just the latest success for the tramway moderne, the first line of the Niçois version having opened in 2007 as part of a larger project that completely renewed the public realm in the main square and shopping street" (p.161). Place Garibaldi and Place Masséna have been transformed from squares in which motorised private vehicles were dominant, to a pedestrianised space traversed by light rail. Thus, the "Grenoble Effect" acts "as an opportunity for cities to redefine their projects in terms of urban planning and land use areas by rehabilitating and restructuring the urban fabric: reorganization of residential areas, recreational, and work zones, and reconquest of urban space, downtown revitalization, renovation of facades etc." (Boquet 2015:13; Chen 2014; Hass-Klau et al. 2004; Olesen and Lassen 2016). Here again, geography matters as these success stories of transport and urban planning integration rely upon political and financial organisation that operates differently in France from other countries where the 'wrong' type of institutional frameworks are unable to support schemes to realise the 'Grenoble Effect' (Chen 2014; Hass-Klau et al. 2004). For instance, in UK, the integrated planning and transit that has been associated with economic growth in Salford Quays and Canary Wharf, is perhaps more akin to the place-making strategies of urban regeneration projects and TOD, than the more aesthetic landscaping practices familiarised under French spatial planning initiatives. This is somewhat of a generalisation, but we see in both sets of processes that light rail acts as a catalyst to stimulate reshaping and restructuring of urban spaces and human relations within them. One further form of city 
boosterism that planners have implemented alongside light rail, is the visual and environmental process of greening the city.

\subsubsection{Greening the city}

'Greening' the city by (re)introducing nature through extensive grass, tree and flower-planting programmes is one of the key findings linking light rail with city image and quality. This is driven by the type of integrated transport and urban development projects that are explained above, and the impact has been visual transformations of city areas. In Angers, for example, 70 percent of the tracks are green which "mediate the vision of an aesthetically beautiful system" (Olesen 2014, p.14). In Reims, 1,700 trees, 34,800 bushes and more than 80,000 square metres of lawn were planted in and around the new tram network (Boquet 2015). New green corridors within the city are not unusual to raise the appearance of light rail in France with Grenoble and Nantes as two further examples. In Mulhouse, in particular, the tram runs for much of its route on lawn track (Figure 6). Elsewhere, light rail in Ørestad New Town, Copenhagen, was part of a larger urban development project where one third of space was "allocated for parks, green areas, lakes and artificial canals" (Knowles 2012:258). However, this development took place on reclaimed land, thus literally creating new space. In Croydon, Tramlink "helped to create new green spaces, enabled the planting of more trees and made parks and rivers more accessible" (Colin Buchanan and Partners 2003:4). These types of recreational city spaces provide important settings associated with promoting healthier lifestyles and more open and sociable spaces. This has been achieved in Bordeaux, where light rail provided a vital link across the river Garonne and made "the right bank a possible place of attraction for inhabitants of Bordeaux [from the left bank], thanks to green spaces it offers or cultural facilities that have been installed" (Sari 2015:234). This has also brought about the mixing of two different socio-demographic groups in one space.

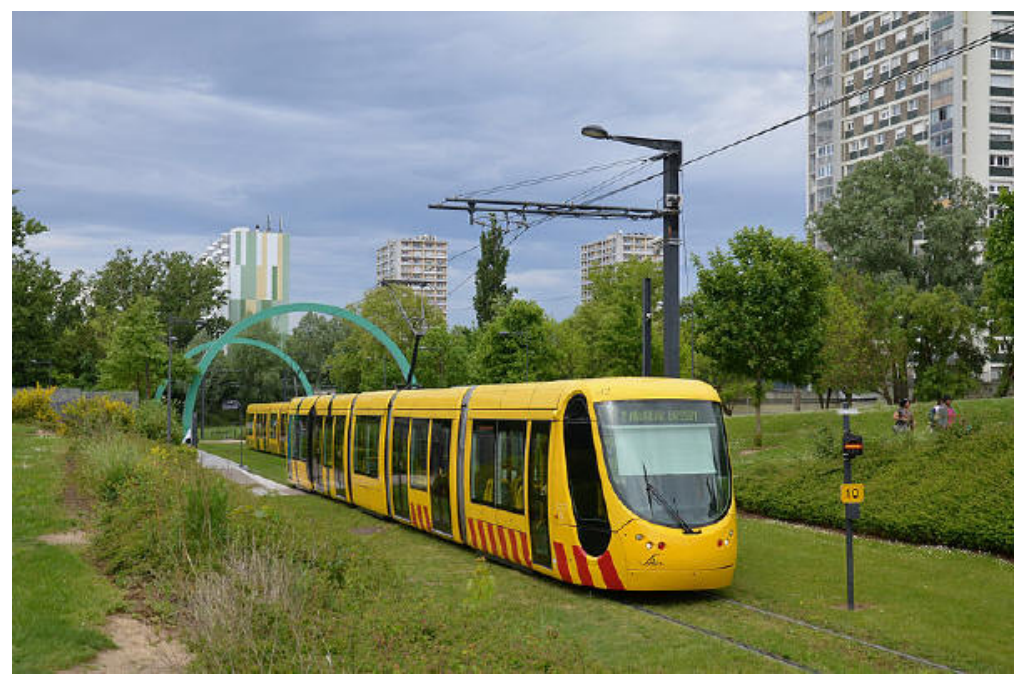

Figure 6: Mulhouse lawn track. Source: Wikimedia Commons: Transports Urbains Français

The 'Grenoble Effect' and greening of the city feature frequently in light rail literature and represent material impacts in the place-making process, which boost city image and quality towards the creation of attractive sustainable and liveable cities. Potential negative impacts did 
not feature in such evaluative literature, although one might imagine that the expansion of pedestrianised areas are less appealing to some motorists who used to be able to access such spaces with private vehicles, or those people who feel excluded from such areas (those with restricted physical mobility, for example). Further research examining the range of meanings that social actors/city users ascribe to light rail is vital to identify potential conflicts and address how places might be improved to benefit a greater majority of its users.

\section{Conclusions}

A main aim of this critical review paper was to conceptualise the relationship between light rail development and city boosterism as one of place-making processes, in order to understand what light rail can do for city image and quality. With increasing awareness of discourses and decisionmaking that value more subjective interpretations of the city - i.e. its attractiveness, quality and liveability (Hensher 2016; Mulliner and Maliene 2011; Vuchic 1999), this qualitative synthesis of existing literature is timely and addresses a methodological gap in existing light rail research. While there is much of significance to draw out about the nature of evidence on which this work is based, and thus to make recommendations for further research, we first set out some provisional conclusions on the relationship between light rail and city boosterism.

Initially examining ideas and perceptions associated with light rail, its symbolism as a modern system that signifies progress and development, and an opportunity to boost existing ideas about a city (its cultural identity) is evident from a range of different stakeholders in different cities. This is captured both in terms of the aesthetics and technologies of the system, and in some comparisons with BRT, though research indicates that LRT/BRT comparisons are often poor indicators of the strengths (and weaknesses) of a particular transit mode. A modern image of light rail can also be a distinctive feature in the valuation of city prestige as a leading or 'world-class' city, though these valuations emerge more among social actors within the cities in question, rather than from social actors outside of these cities. This is unsurprising given the opportunity to promote the virtues of light rail in a particular city, particularly for politicians, developers, business leaders and transit agencies. This indicates the central role that light rail might play (over other transport) in city boosterism, but does not help to expose alternative narratives. Furthermore, such impressions of light rail and its status have largely been taken for granted (particularly in comparison with BRT). For example, cities with efficient BRT are assumed to be second-tier cities on the world stage (Paget-Seekins 2015), which overlooks the possibility that bus, rather than light rail, is a more appropriate mode of transit based on the internal geographies and attributes of particular cities (Cain and Flynn 2013; Hensher 2016). If taken-for-granted, cities risk overestimating or underestimating the opportunities that can be gained from different transit modes in specific cities.

In contrast, design features of light rail have been used quite deliberately, particularly in French cities, to enhance attributes already used to promote a particular place-image and identity about a city. The meaning of design features is much clearer in the literature than compared with 
valuations of light rail as a 'modern' system, demonstrating how light rail is actively and knowingly incorporated into continual processes of place-making. In addition, many European and US cities demonstrate, through integrating transport infrastructure with urban planning and land-use (TOD and the 'Grenoble effect', for instance), how light rail is treated as a vehicle to transform urban areas and boost image and quality from small-scale street improvements to city-wide enhancementin some locations. Place-making is particularly evident here as a strategy by city planners and developers towards achieving sustainability principles and more liveable cities. That being said, in recognising that place-making impacts vary at geographical scales, one implication of such variation is that certain streets, quarters, or areas of a city may be neglected altogether, thus generating uneven pockets of improvement. Where different sectors of the population live in relation to these is a further question for analysis.

Overall, this paper enriches our understanding of light rail as an agent in city-making, for it brings together a range of empirical evidence that provides a foundation for further research, not only in terms of indicating the strength and signification of emerging enquiry into transit image and city boosterism, but also to address some of the weaknesses of existing evidence towards more robust analysis. Data on which this paper draws are geographically patchy and analytically incomplete. Too often, we found that the perceptions of various social actors were not sufficiently explained or contextualised to understand the meaning behind certain words or phrases, a critique noted by others (Hass-Klau et al. 2003). This demonstrates, to some extent, how ideas about light rail may be taken for granted, i.e. that they will be understood by other social actors without deeper explanation. However, this is also a product of research enquiries, which have rarely made ideas and perceptions of light rail a primary goal in research. Thus, to deconstruct the meanings behind the words and ideas held by social actors has likely been of less importance than an alternative focus in research. What we are left with is a strong impression of how light rail is valued, rather then in-depth understanding.

In addition, systematic research aimed to capture a range of stakeholder views about light rail in a particular city, was absent from literature. In particular_particular, we know that transit has negatively impacted certain sectors of the population (i.e. through displacement of housing or unaffordability of light rail fares) (Grengs 2005), yet the absence of voices to tell these personal stories (alongside those more positive ones illustrated here), results in marginalisation of certain actors and gives the impression that light rail is more positive than a systematic analysis might revealother populations might perceive.- There are at least two avenues for future research in this vein: on the one hand, a systematic (perhaps comparative) analysis of different stakeholders' views. Qualitative, semi-structured interviews would provide some framework for comparison but a level of openness to enable meanings and interpretations to be examined. This type of approach might work best for those stakeholders who are able to talk directly about transit impact and city image. On the other hand, and this may be the greater challenge for future research, the voices that have been neglected - displaced populations, marginalised populations, transit-user and nonuser groups, for instance - are less likely to discuss negative (or positive) impacts as 'city image', 
though their experiences may certainly shape their views about the different city areas. More intensive ethnographic and participatory research would potentially work best to unpack, understand and flesh out the experiences and feelings relevant to these groups.

Moreover, experiences from different cities, while geographically and historically specific, would help to provide depth and a sense of comparison of impacts across the globe, particularly for those eities with light rail that appear to be less well researched or neglected altogether (Ferbrache and Know 2016).

These critiques raised from-of existing evidence mean that our conclusions about the role of light rail in boosting city image and quality are provisional, though even with more systematic research, a qualitative view will always offer only a partial insight. Nevertheless, we make further recommendations for future research to include:

- In-depth qualitative methods to capture better the meanings and significance that social actors ascribe to light rail, particularly to better understand how different social actors use terms such as 'benefit', 'impact' and 'quality'.

- Systematic examination of the views of multiple stakeholders to draw attention to the range of perceptions held about a particular light rail system. In this way, research can provide insight to areas of contestation as well as better understanding of social equality impacts.

- Longitudinal research designed to capture changing perceptions and material transformations in the continual (re)production of places (Massey 2005). This may be beneficial for longer-term planning: as systems age, the modern features of light rail, and subsequently the modern sense of place may be challenged or replaced by newer technologies and aesthetics (as already witnessed with the development of sub-surface APS power systems pioneered in Bordeaux, rather than visually intrusive overhead wires). Moreover, many cities (particularly in Europe, but also in the US) with light rail, have already seen the rise and decline of former street running tram (American streetcar) systems that were introduced in the late 19th century (Boquet 2015; Hass-Klau et al. 2004). This may offer an historical framework for conceptualising more modern systems.

Overall, our recommendations are for further systematic research based on a cultural geographic lens that complements and expands existing insights from transport geography (Cresswell and Merriman 2010; Olesen and Lassen 2016; Shaw and Hesse 2010; Shaw and Sidaway 2011). Cultural geographers, urban scholars or transport researchers may wish to take this up as transport clearly has a dynamic and powerful impact on the visions and place-making strategies of current and future cities, thus expanding a cultural geographic perspective on transport and addressing increasing significance of image and quality in emergent ideas about future cities. 


\section{References}

Alpkokin, P. and Ergun, M. 2012. Istanbul Metrobus: first intercontinental bus rapid transit. Journal of Transport Geography 24:58-66

Appadurai, A. 1990. Disjuncture and difference in the global cultural economy. Theory, Culture and Society, 7, 295-310.

Arrington, G.B., 2009. Portland's TOD evolution: from planning to lifestyle. In: Curtis, C., Renne, J.L. and Bertolini, L. (eds), Transit Oriented Development: making it happen, Farnham, UK and Burlington, Vermont, USA: Ashgate Publishing, pp. 109-124

Babalik, E. 2000. Urban Rail Systems: A Planning Framework to Increase Their Success. Thesis submitted to the University of London for the degree of Ph.D. London: University of London.

Babalik-Sutcliffe, E., 2002. Urban rail systems: analysis of the factors behind success. Transport Reviews 22 (4): 415-447

Banister, D. and Berechman, J., 2001. Transport investment and the promotion of economic growth. Journal of Transport Geography, 9:209-218

Banister, D. and Thurstain-Goodwin, M., 2011. Quantification of the non-transport benefits resulting from rail investment. Journal of Transport Geography, 19:212-223

Bernick and Cervero, R., 1997. Transit Villages for the 21st Century, New York: McGraw-Hill

Boschken, H. L. 2003. Global cities, systemic power, and upper-middle-class influence. Urban Affairs Review, 38:808-830

Boquet, Y. Unpublished results. The renaissance of tramways and urban redevelopment in France. Unpublished paper. Bourgogne: University of Bourgogne.

Cain, A. and Flynn, J. 2013. Examining the ridership attraction potential of bus rapid transit: a quantitative analysis of image and perception. Journal of Public Transportation 16(4):63-82

Cervero, R., 1998 The Transit Metropolis: A Global Inquiry, Washington DC: Island Press

Chen, C.-L. (2014) The wider impacts of rail-based transport investment on urban and economic development, Technical Report. Bartlett School of Planning: University College London.

$\mathrm{CfIT}, 2001$. European best practice in delivering integrated transport. London: Commission for Integrated Transport 
Clark, C. 1958. Transport - maker and breaker of cities. The Town Planning Review 28(4):237-250

Colin Buchanan and Partners, 2003. Economic and regeneration impact of Tramlink. Report for the South London Partnership, funded by the London Development Agency. Transport for London and the London Boroughs of Croydon \& Sutton, July 2003

Cresswell, T. 2006. On the move: Mobility in the modern Western World. London: Routledge.

Cresswell, T. and Merriman, P. 2010 Introduction: Geographies of Mobilities - Practices, Spaces, Subjects. In Cresswell, T. \& Merriman, P. (eds.) Geographies of Mobilities: Practices, Spaces, Subjects. Farnham: Ashgate.

Crocker, S., Dabinett, G., Gore, T., Haywood, R., Hennebury, J., Herrington, A., Kirkpatrick, A., Lawless, P. and Townroe, P., 2000. Monitoring the economic and development impact of South Yorkshire Supertram, Sheffield: Centre for Regional Economic and Social Research, Sheffield Hallam University

Dabinett, G., Gore, T., Haywood, R. and Lawless, P., 1999. Transport investment and regeneration, Sheffield: 1992-1997. Transport Policy, 6:123-134

de Bruijn, H.D., Veeneman, W., 2009. Decision-making for light rail. Transportation Research Part A 43 (4):349-359.

DETR [Department of the Environment, Transport and the Regions]. 2000. Building a better quality of life: a strategy for more sustainable construction. London: DETR

DETR and CABE [Commission for Architecture and the Built Environment]. 2000. By design Urban design in the planning system: towards better practice. London: Thomas Telford.

Dorsey, B. and Mulder, A., 2013. Planning, place-making and building consensus for transitoriented development: Ogden, Utah case study. Journal of Transport Geography, 32:65-76

Edwards, M. \& Mackett, R.L. 1996. Developing new urban public transport. Transport Policy 3 (4):225-239

Entrikin, J. N. (1991). The characterization of place. Worcester, MA: Clark University Press. European Commission 2010. Making Our Cities Attractive and Sustainable: How the EU Contributes to Improving the Urban Environment. Luxembourg: Publications Office of the European Union 
Farmer, S., 2011. Uneven public transportation development in neoliberalizing Chicago, USA. Environment and Planning A. 43:1154-1172.

Ferbrache, F. and Knowles, R.D. 2016. Generating Opportunities for City Sustainability through Investments in Light Rail Systems: Introduction to the Special Section on Light Rail and Urban Sustainability. Journal of Transport Geography. 54: 369-372

Frug, G. E. (2001). City making: Building communities without building walls. Princeton, NJ: Princeton University Press.

Grengs, J. 2005. The abandoned social goals of public transit in the neoliberal city of the USA. City, 9, 51-66.

Groneck, C. and Schwandl, R. 2014. Tram Atlas France. Druck: Berlin.

Hass-Klau, C., Crampton, G., Biereth, C. and Deutsch, V. 2003. Bus or Light Rail: Making the Right Choice: a financial operational and demand comparison of light rail, guided buses, busways and bus lanes. Second Edition. Environment and Transport Planning: Bergische Universität Wuppertal.

Hass-Klau, C., Crampton, G.R. and Benjari, R., 2004. Economic impacts of light rail: the results for 15 urban areas in France, Germany, UK and North America. Environmental and Transport Planning, UK: Brighton

Hensher, D.A. and Mulley, C. 2015. Modal image: candidate drivers of preference differences for BRT and LRT. Transportation. 42:7-23

Hensher, D.A. 2016. Why is light rail starting to dominate bus rapid transit again? Transport Reviews 36(3):289-292

Hickman, R., Hall, P., and Banister, D., 2013. Planning more for sustainable mobility. Journal of Transport Geography. 33:210-219.

Hidalgo, D. and Gutiérrez, L. 2013. BRT and BHLS around the world: explosive growth, large positive impacts and many issues outstanding. Research in Transportation Economics. 39:8-13

Hodgson, P., Potter, S., Warren, J., Gillingwater, D., 2013. Can bus really be the new tram? Research in Transportation Economics 39 (1):158-166.

Hubbard, P., 2008. City. London: Routledge

Hutchinson, S. 2000. Waiting for the Bus. Social Text. Published by Duke University Press. 
Jensen, O.B. 2013. Staging Mobilities, London, Routledge.

Jensen, O.B. and Richardson, T. 2004. Making European Space: Mobility, Power and Territorial Identity, London, Routledge.

King, D.A. and Fischer, L.A. 2016 Streetcar projects as spatial planning: a shift in transport planning in the United States. Journal of Transport Geography, 54:383-390

Knowles, R.D., 1992. Light rail transport. In: Whitelegg, J. (ed.) Traffic Congestion: is there a way out? Hawes: Leading Edge Press:107-133

Knowles, R.D. 1996. Transport impacts of Greater Manchester's Metrolink light rail system. Journal of Transport Geography, 4(1):1-14

Knowles, R.D., 2000. Light rail transit's impacts in British and Canadian cities. Paper presented at the Association of American Geographers Annual Meeting, USA: Pittsburgh, April 62000

Knowles, R.D., 2006. Transport shaping space: differential collapse in time-space. Journal of Transport Geography, 14: 407-425

Knowles, R.D., 2012. Transit Oriented Development in Copenhagen, Denmark: from the Finger Plan to Ørestad. Journal of Transport Geography, 22:251-261

Knowles, R.D. and Ferbrache, F., 2014. An investigation into the Economic Impacts on Cities of Investment in Light Rail Systems, Report for UKTram, Birmingham, UK

Knowles, R.D. and Ferbrache, F. 2015. Evaluation of wider economic impacts of light rail investment on cities. Journal of Transport Geography, 54:430-439

Lavery, T.A. and Kanaroglou, P., 2012. Rediscovering light rail: Assessing the potential impacts of a light rail transit line on transit oriented development and transit ridership. Transportation Letters, $4(4): 211-226$

Lawless, P. and Gore, T. 1999. Urban regeneration and transport investment: a case study of Sheffield 1992-96. Urban Studies, 36(3):527-545

Lefebvre, H. 1991. The production of space. Oxford: Blackwell

Loo, B.P.Y., Chen, C. and Chan, E.T.H., 2010. Rail-based transit-oriented development: lessons from New York City and Hong Kong. Landscape and Urban Planning, 97:202-212 
Mackett, R.I. and Edwards, M., 1998. The impact of new urban public transport systems: will the expectations be met? Transportation Research A, 32(4):231-245

Massey, D. 2005 For Space. London: Sage

McCann, E. J. 2002. The cultural politics of local economic development : meaning-making, placemaking, and the urban policy process. Geoforum, 33:385-398

McKie, R. 2014. Edinburgh's tram system opens - $£ 374 m$ over budget and three years late. The Observer. 01 June 2014. Available at: http://www.theguardian.com/uknews/2014/jun/01/edinburgh-tram-system-opens> accessed 29.03.16

McLellan, A. and Collins, D. 2014. "If you're just a bus community... you're second tier": motivations for rapid mass transit (RMT) development in two mid-sized cities. Urban Policy and Research 32(2):203-217

Mulliner, E. and Maliene, V. 2011. Attractive places to live. Urban Design International. 16:147-152

Newman, P. and Thornley, A. 1995. Euralille: "boosterism' at the centre of Europe. European Urban and Regional Studies 2(3):237-246

Niedzielski, M. \& Malecki, E. 2011. Making Tracks: Rail Networks in World Cities. Annals of the Association of American Geographers, 102:1409-1431

Nikitas, A. and Karlsson, M. 2015. A worldwide state-of-the-art analysis for bus rapid transit: looking for the success formula. Journal of Public Transportation 18(1):1-33

Nolte, A. and Yacobi, H. 2015. Politics, infrastructure and representation: the case of Jerusalem's light rail. Cities. 43:28-36

ODPM [Office of the Deputy Prime Minister] 2005. Sustainable Communities: people, places and prosperity. London: ODPM

Olesen, M. 2014. Framing light rail Projects - Case studies from Bergen, Angers and Bern. Case Studies on Transport Policy. 2:10-19

Olesen, M. and Lassen, C. 2016. Rationalities and materialities of Light Rail Scapes. Journal of Transport Geography. 54: 373-382

Oscar Faber, 2002. Croydon Tramlink Impact Study: Summary Report, Transport for London 
Paget-Seekins, L. 2015. Bus rapid transit as a neoliberal contradiction. Journal of Transport Geography 48:115-120

Pickrell, D.H. 1992. A desire named streetcar: fantasy and fact in rail transit planning. American Planning Association. Journal of the American Planning Association. 58(2):158-176

Priemus, H. and Konings, R. 2001. Light rail in urban regions: What Dutch policymakers could learn from experiences in France, Germany and Japan. Journal of Transport Geography, 9(3):187-198

Roger Tym \& Partners Ltd, 1996. Forecast Employment at 1998 and 2013 in the Pomona/Cornbrook, Exchange Quay, Salford Quays and Eccles Development Areas. In association with Greater Manchester PTE, Manchester

Sari, F. 2015. Public transit and labor market outcomes: analysis of the connections in the French agglomeration of Bordeaux. Transportation Research Part A. 78:231-251

SDG [Steer Davies Gleave] 2005. What Light Rail can do for Cities: a review of the evidence. Final Report, London: Steer Davies Gleave

Shaw, J. and Docherty, I., 2014. The Transport Debate, Bristol: Policy Press

Shaw, J. and Hesse, M. 2010. Transport, geography and the 'new' mobilities. Transactions of the Institute of British Geographers. 35:305-312

Shaw, J. \& Sidaway, J. D. 2011. Making links: on (re)engaging with transport and transport geography. Progress in Human Geography, 35, 502-520.

Sheller, M., \& Urry, J. (2006). The new mobilities paradigm. Environment and Planning A vol. 38:207-226

Shields, R. 1991. Places on the Margin: alternative geographies of modernity. London: Routledge

Thomson J.M. 1978. Great Cities and Their Traffic. Peregrine Books: Harmondsworth, Middlesex

Urban Task Force. 1999. Towards an Urban Renaissance. London: Urban Task Force.

URBED (2014) Oxford Futures: transport options, London, URBED. Available online at: http://urbed.coop/sites/default/files/Oxford\%20Transport\%200ptions\%20Report.pdf (accessed 21 March 2016) 
Van den Berg, L., Van der Meer, J. and Otgar, A.H.J. 1999. The attractive city: catalyst for economic development and social revitalization. European Institute for Comparative Urban Research (EURICUR): Erasmus University Rotterdam.

van Wee, B. and Rietveld, P., 2013. CBA: ex ante evaluation of mega-projects. In: Priemus, H. and van Wee, B. (eds), International Handbook on Mega-Projects, Cheltenham: Edward Elgar 269-290

Vincent, W. 2010. Bus rapid transit in the United States. Built Environment 36(3):298-306

Vuchic, V.R. 1999. Transportation for livable cities. New Brunswick, N.J: Center for Urban Policy Research

Walmsley, D. and Perrett, K., 1992. The effects of rapid transit on public transport and urban development, London: The Stationery Office

Weinstock, A., Hook, W., Replogle, M., Cruz, R., 2011. Recapturing global leadership in bus rapid transit: a survey of select U.S. cities. Retrieved from www.itdp.org:

http://www.itdp.org/documents/20110526ITDP_USBRT_Report-LR.pdf (July 2013)

Wood, A. 2015. The politics of policy circulation: unpacking the relationship between South African and South American cities in the adoption of bus rapid transit. Antipode. 47:1062-1079

\section{Figure captions:}

Figure 1: The 'Bordeaux Transformation': wireless trams create a sleek, modern image in the city centre. Source: Wikimedia Commons: Marie-Michèle Mailhot

Figure 2: Vancouver SkyTrain helped to raise the profile of the city. Source: Wikimedia Commons: Haizhebear

Figure 3: The iconic ' $M$ ' logo of the Tyne and Wear Metro. Source: Wikimedia Commons: wfmillar

Figure 4: Copenhagen metro on elevated tracks in front of Rambøll Engineering, Ørestad City. Source: Wikimedia Commons: Mdann52talk to me!

Figure 5: The 'Grenoble Effect': Landscape changes before and after implementation of light rail. Source: Pitrel, 2008

Figure 6: Mulhouse lawn track. Source: Wikimedia Commons: Transports Urbains Français 